\title{
Høydosebehandling med autolog stamcellestøtte ved lymfom - fra utprøvende til standard behandling
}

\begin{abstract}
Høydosebehandling med autolog stamcellestøtte (HMAS) har vært et terapialternativ ved lymfomer i Norge helt siden 1987. Ved å gjenopprette beinmargsfunksjonen via tilbakeføring av pasientens egne stamceller kan man gi kreftbehandling i høyere og ellers dødelige doser og dermed oppnå bedre behandlingsresultater. Opprinnelig ble stamcellene høstet fra beinmarg og høydosebehandlingen inkluderte helkroppsbestråling, men fra midten av 1990-

årene har man høstet stamceller venøst og høydosebehandlingen har bestått i kjemoterapi alene (BEAM-kur). I 1995 ble behandlingen regionalisert og er siden blitt gjennomført i alle helseregioner. HMAS-prosedyren ble innført som utprøvende behandling i kliniske studier med internasjonalt samarbeid. Indikasjonene har endret seg over tid, og dette er nå etablert behandling ved en rekke lymfomtyper.
\end{abstract}

I Norge har det siden 1987 vært gitt høydosebehandling med autolog stamcellestøtte (HMAS) ved lymfomer. Behandlingen består av intensiv kjemoterapi og/ eller helkroppsbestråling i så store doser at det medfører livstruende tap av friske bloddannende stamceller i beinmargen. For å bevare fremtidig beinmargsfunksjon blir stamceller høstet fra pasienten før høydosebehandlingen gis, fryst ned og tilbakeført noen dager etterpå (fig 1). Fra 1987 til 1995 besto selve høydosebehandlingen av helkroppsbestråling etterfulgt av kjemoterapi i form av høydose cyklofosfamid. Fra 1996 har man som oftest brukt kjemoterapi alene (BEAM: karmustin (BCNU), etoposid, cytarabin (Ara-C), melfalan). I midten av 1990-årene ble også stamcellehøstingen endret. Man gikk da over til å høste stamceller fra blod (via sentralvenøst kateter) og ikke fra beinmarg, som krevde narkose. Høsting av stamceller fra blod har også den fordelen at beinmargsfunksjonen gjenopprettes raskere, med følgende mindre behandlingsrelatert sykelighet, mindre bruk av antibiotika og blodprodukter, og dermed også lavere kostnader (1).

Lymfomer er en heterogen gruppe kreftsykdommer som utgår fra lymfocytter. De inndeles i Hodgkins og non-Hodgkins lymfom. Non-Hodgkins lymfom er igjen inndelt i mer enn 30 typer (2). Omtrent 90 \% av non-Hodgkins lymfomer utgår fra B-cellerekken, mens T-cellelymfomer utgjør ca. $10 \%$. En tradisjonell inndeling skiller de klinisk aggressive lymfomene (omfatter blant annet diffust storcellet Bcellelymfom og de fleste modne T-cellelymfomer), de svært aggressive formene (Burkitts lymfom og lymfoblastisk lymfom) og de indolente lymfomene (hvorav follikulært lymfom er vanligst) (3). Til sammen utgjør lymfomene ca. $4 \%$ av alle nye krefttilfeller i Norge (4).

Insidensen av Hodgkins lymfom har vært stabil de siste 50 årene, og i 2010 ble 130 non-Hodgkins lymfom har insidensen vært økende, med 964 nye tilfeller i 2010 (4). Bedre diagnostikk og behandling gjennom flere tiår har gitt høyere overlevelse, og femårs relativ overlevelse er nå på ca. $90 \%$ for Hodgkins lymfom og på ca. $70 \%$ for alle non-Hodgkins lymfomer sett under ett (4). Imidlertid varierer femårsoverlevelsen for lymfomer med stadium, histologisk undergruppe, pasientens alder og kliniske og prognostiske faktorer.

For Hodgkins lymfom og aggressive og svært aggressive lymfomer vil moderne kreftbehandling ofte føre til helbredelse (3). De indolente lymfomene har et mer langtrukket forløp. Kurasjon med konvensjonell behandling er ikke en realistisk målsetting for disse pasientene, men behandlingen reduserer sykdomsaktiviteten og forlenger livet $(3,5)$. Indolente lymfomer kan hos en del pasienter med tiden endre vekstmønster og histologisk utseende og bli mer lik de aggressive formene, noe som kalles transformasjon (6). Enkelte typer av lymfomer innebærer fortsatt dårlig prognose. Dette gjelder for eksempel mantelcellelymfom, perifere T-cellelymfomer og transformerte indolente lymfomer (3).

Høydosebehandling med autolog stamcellestøtte er svært intensiv og ressurskrevende. Dette har vært en behandlingsmulighet ved lymfomer de siste 25 årene og gir en klar overlevelsesgevinst ved flere lymfomtyper. Vi ønsker med denne artikkelen å gi en historisk oversikt over HMAS-bruken ved lymfomer i Norge. nye tilfeller meldt til Kreftregisteret (4). For

\author{
Knut Bjøro Smeland \\ knusme@ous-hf.no \\ Cecilie E. Kiserud \\ Nasjonal kompetansetjeneste for seneffekter \\ Avdeling for kreftbehandling \\ Oslo universitetssykehus
}

\section{Grete F. Lauritzsen}

Alexander Fosså

Avdeling for kreftbehandling

Oslo universitetssykehus

\section{Jens Hammerstrøm}

Avdeling for blodsykdommer

St. Olavs hospital

\section{Vidar Jetne}

Avdeling for medisinsk fysikk

Oslo universitetssykehus

\section{Arne Kolstad}

Gunnar Kvalheim

Avdeling for kreftbehandling

Oslo universitetssykehus

\section{Jon Håvard Loge}

Nasjonal kompetansetjeneste for seneffekter

Oslo universitetssykehus

Avdeling for kreftbehandling

og

Avdeling for atferdsfag

Det medisinske fakultet

Universitetet i Oslo

\section{Turid Løkeland}

Avdeling for kreftbehandling og medisinsk fysikk Haukeland universitetssykehus

\section{Jon Magnus Tangen}

Avdeling for blodsykdommer

Oslo universitetssykehus

\section{Harald Holte}

Avdeling for kreftbehandling

Oslo universitetssykehus

\section{Stein Kvaløy}

Kreft-, kirurgi- og transplantasjonsklinikken Oslo universitetssykehus

og

Institutt for klinisk medisin

Det medisinske fakultet

Universitetet i Oslo 


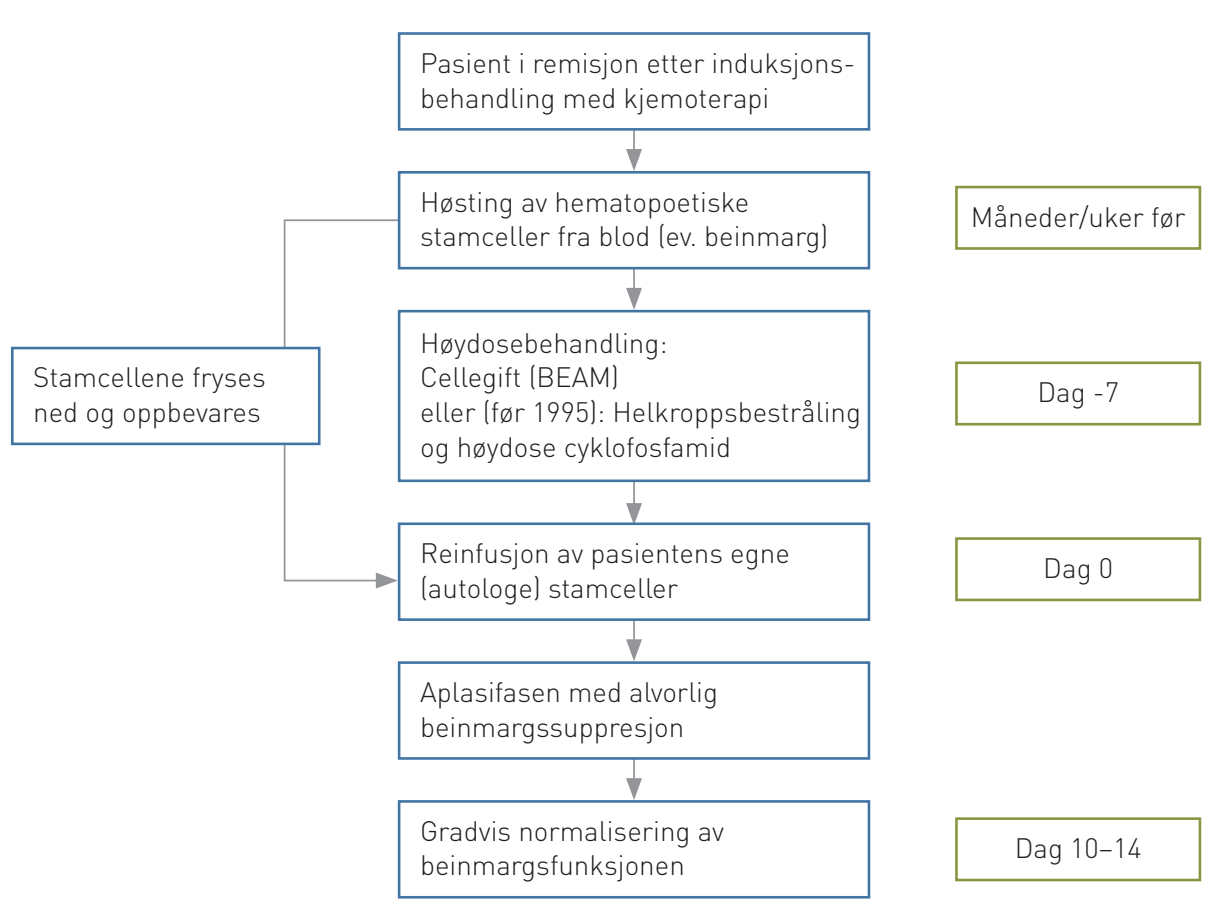

Figur 1 Slik gjennomføres høydosebehandling med autolog stamcellestøtte (HMAS) ved lymfomer. Trinn 1. Induksjonsbehandling: For å gjennomføre behandlingen er det en forutsetning at lymfomet er kjemosensitivt, og pasienten gjennomgår først forbehandling/induksjonsbehandling med ulike kjemoterapiregimer avhengig av diagnose. Trinn 2. Stamcellehøsting: Hvis lymfomet oppnår minst partiell respons på forbehandlingen, går pasienten videre til stamcellehøsting. Dette giøres i dag fra venøst blod etter at stamcellene er blitt mobilisert ut fra beinmargen til perifert blod ved hjelp av vekstfaktor (G-CSF - granulocyte colony-stimulating factor) i kombinasjon med kjemoterapi. Trinn 3. Stamcellene fryses ned i flytende nitrogen og oppbevares mens pasienten mottar selve høydosebehandlingen. Trinn 4. Høydosebehandlingen: I perioden 1987-95 besto behandlingen av helkroppsbestråling med totaldose 13 Gy gitt over fem dager med to fraksjoner à 1,3 Gy dag lig kombinert med kjemoterapi i form av høydose cyklofosfamid. Fra 1996 har man brukt kjemoterapi alene med BEAM (karmustin (BCNU), etoposid, cytarabin (Ara-C) og melfalan). Trinn 5. Reinfusjon av stamceller: Etter fullført kur blir stamcellene reinfundert via sentralvenøst kateter og finner veien tilbake til beinmargen. Trinn 6. Aplasifasen: Mens beinmargen regenereres med proliferasjon, differensiering og modning av de forskjellige cellelinjene, vil pasienten være pancytopen uten ny produksjon av erytrocytter, trombocytter og granulocytter. Pasienten ligger i denne perioden i isolat og er avhengig av høyspesialisert støttebehandling. Trinn 7. Gradvis normalisering av beinmargsfunksjonen: Etter 10-14 dager, når nivået av nøytrofile granulocytter stiger, kan isolatet oppheves. Beinmargsfunksjonen vil gradvis restitueres slik at nivået av sirkulerende blodceller normaliseres

\section{Kunnskapsgrunnlag}

Artikkelen er bygd på litteratursøk i PubMed, innhenting av samtlige behandlingsprotokoller for HMAS-studier med norsk deltakelse samt personlig erfaring fra behandlingsmiljøene. Studier som det norske miljøet har deltatt i, er vektlagt.

\section{Høydosebehandling med autolog stamcellestøtte ved lymfomer}

Den første dokumenterte allogene stamcelletransplantasjonen (det vil si stamceller fra fremmed giver) ble gjennomført allerede i 1939, da en kvinne med aplastisk anemi fikk overført beinmarg fra sin bror ved intravenøs transfusjon (7). Behandlingen var mislykket, og pasienten døde etter fem dager. I 1950-årene viste dyreforsøk at man kunne overkomme ellers dødelig beinmargssuppresjon ved å gi beinmarg intravenøst (8). Dette skyldtes at de transfunderte stamcellene rekoloniserte beinmargen og gjenopprettet beinmargsfunksjonen.

Beinmargssuppresjon er den bivirkningen som i sterkest grad begrenser behandlingsmengden ved mange typer kjemoterapi og strålebehandling. Det ble reist en hypotese om at autolog stamcellestøtte kunne overkomme denne og at dosene kunne økes, med tilsvarende større behandlingseffekt. Det ble derfor gjennomført flere kliniske studier i slutten av 1950-årene og i begynnelsen av 1960-årene hvor man benyttet pasientens egne stamceller (9). Resultatene av disse første kliniske studiene var skuffende, men i kjølvannet av lovende resultater ved allogen stamcelletransplantasjon for leukemi ble konseptet igjen utforsket i 1970-årene. De første vellykkede resultatene av HMASbehandling ved lymfom ble publisert i 1978 (10), og i løpet av 1980-årene ble det gjen- nomført flere fase 1- og fase 2-studier med lovende resultater (11).

I Norge ble behandlingen etablert på Radiumhospitalet gjennom tre fase 2-studier fra 1987. Disse første studiene inkluderte selekterte pasienter fra hele landet som var under 55 år, i god allmenntilstand, med lite komorbiditet og med lymfomer som hadde svært dårlig prognose med datidens behandling. Denne besto i hovedsak av CHOP-basert kjemoterapi (cyklofosfamid, doksorubicin, vinkristin, prednisolon). I en 20-månedersperiode i 1988-89 fikk fem pasienter selve høydosebehandlingen i Heidelberg i Tyskland av driftsmessige årsaker.

I de påfølgende årene ble nye internasjonale multisenter fase 2- og fase 3-studier lansert (fig 2) (12-22). I 1993 opprettet derfor Helsedirektoratet en faggruppe for høydosebehandling med autolog stamcellestøtte ved maligne lidelser. Gruppen ble bedt om å gi tilrådning om hvilket omfang og i hvilken form behandlingstilbudet burde gis i Norge (23). Begrunnelsen var at det var behov for oversikt over et felt i rask utvikling - et område med lovende resultater, men hvor behandlingens plass i helsevesenet ikke var avklart. Stein Kvaløy ble oppnevnt som leder, og faggruppen leverte i 1995 sin rapport. Konklusjonene var at høydosebehandling med autolog stamcellestøtte kunne regnes som etablert prosedyre ved aggressive lymfomer i annen remisjon og at den var en lovende, men fortsatt utprøvende behandlingsform ved en rekke andre indikasjoner (23).

Rapporten definerte samtidig krav til dokumentasjon for at HMAS-behandling kunne anses som etablert terapi ved en ny diagnosegruppe: Minst to påfølgende fase 3studier med adekvat design som viste nytte av behandlingen, uten at samtidige studier av samme kvalitet viste andre resultater (gjaldt hyppige kreftformer), eller minst tre påfølgende fase 2-studier (aktuelt for sjeldnere kreftformer). Videre ble det konkludert med at HMAS-bruken hadde økt, både i form av antall behandlede pasienter og antall indikasjoner, og at virksomheten burde regionaliseres. Fra 1996 ble derfor behandlingen gitt $i$ alle helseregionene: ved Radiumhospitalet og Ullevål universitetssykehus i Oslo (nå Oslo universitetssykehus), ved Haukeland universitetssykehus i Bergen, ved St. Olavs hospital i Trondheim og ved Universitetssykehuset Nord-Norge i Tromsø.

\section{Indikasjoner for HMAS-behandling} ved lymfomer i perioden 1987-2012 Figur 2 (12-22) gir en oversikt over studiene og indikasjoner for HMAS-behandling ved lymfomer i Norge fra 1987 og frem til i dag. Slik lymfombehandling ble 


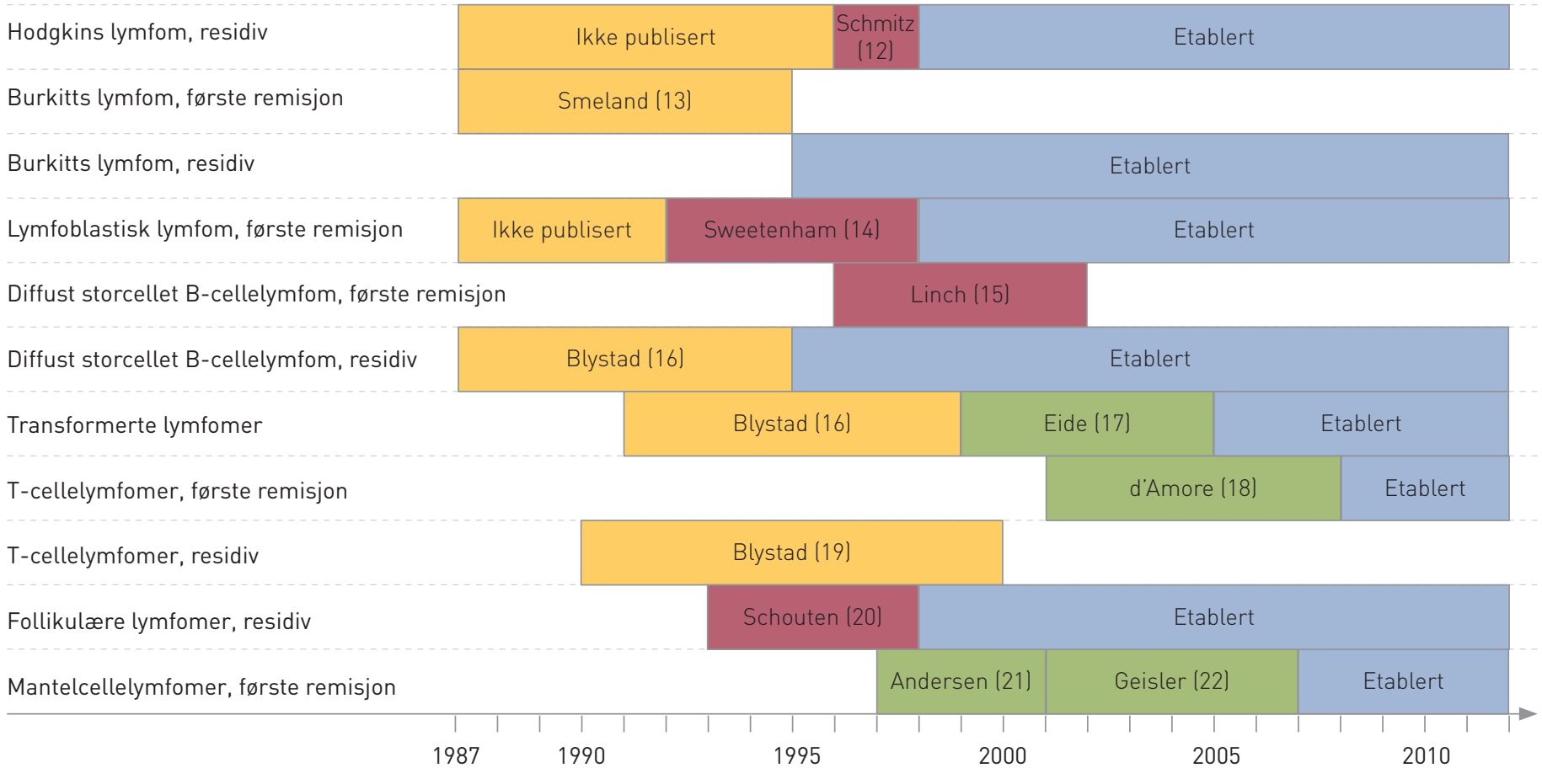

Figur 2 Gjennomføring av studier og etablering av indikasjoner for høydosebehandling med autolog stamcellestøtte for lymfomer i Norge. Gul boks indikerer singelsenter fase 2-studier, grønn multisenter fase 2-studier, rød randomiserte fase 3-studier og blå etablert indikasjon/behandlingsmulighet. Fase 1-studier: Forsøk på et fåtall personer der hensikten hovedsakelig er å kartlegge bivirkninger og tolerabilitet. Fase 2-studier: Utprøvning av ny behandling på en liten gruppe pasienter der hensikten hovedsakelig er å kartlegge effekt og tilpasse dosenivå. Fase 3-studier: Utprøvning av ny behandling mot etablert behandling (eller placebol i et stort pasientmateriale for å dokumentere effekt. Gjerne randomiserte, kontrollerte studier

etablert på Radiumhospitalet i 1987 med tre fase 2-studier for henholdsvis for Hodgkins lymfom (ikke publisert), svært aggressive lymfomer (13) og tilbakefall av aggressive lymfomer (16).

Fra 1996 deltok Radiumhospitalet i en tysk fase 3-studie hvor pasienter med residiv av avansert og/eller høyrisiko Hodgkins lymfom ble randomisert til enten HMASbehandling eller standard kjemoterapi uten stamcellestøtte (12). Denne studien viste signifikant bedre sykdomsfri overlevelse for gruppen som hadde fått HMAS-behandling (55\% mot $34 \%$ etter tre år). Tilsvarende gevinst ved behandlingen for residiv av Hodgkins lymfom var også vist $\mathrm{i}$ en mindre, randomisert studie (24). Disse to studiene er hovedgrunnlaget for dagens etablerte indikasjon for HMAS-behandling ved residiv av Hodgkins lymfom innen to år, ved manglende respons på primærbehandling eller ved andre eller senere residiv $(3,25,26)$.

I fase 2-studien som inkluderte pasienter med Burkitts lymfom medførte HMASbehandling som konsolidering i første remisjon en vesentlig forbedret femårs progresjonsfri overlevelse - fra $31 \%$ til $71 \%$ sammenliknet med historiske kontrollpersoner behandlet med standard CHOP-basert kjemoterapi alene (13). Etter hvert er pri- mærbehandlingen av Burkitts lymfom blitt kraftig forbedret med intensiverte kjemoterapikurer, slik at HMAS-behandling i første remisjon ikke lenger gir noen overlevelsesgevinst (13). Derfor er behandlingen nå anbefalt kun ved primær kjemoresistens eller residiv av Burkitts lymfom $(3,25,27)$.

For lymfoblastisk lymfom er fortsatt HMAS-behandling i første remisjon det alternativet vi anbefaler i Norge, basert på funnene fra en internasjonal randomisert multisenterstudie fra perioden 1992-97, der også norske pasienter ble inkludert. Denne studien viste bedret treårs sykdomsfri overlevelse ved HMAS-behandling sammenliknet med vedlikeholdsbehandling i tradisjonelle doser (14).

HMAS-behandling for diffust storcellet B-cellelymfom (DLBCL) i annen remisjon ble etablert som standard i Norge i 1995 (23), basert på flere fase 2-studier $(16,28)$ og en fase 3-studie (29). Nytten av behandlingen også i første remisjon har vært undersøkt - uten at det er funnet at dette har gitt bedre responsrater eller høyere overlevelse $(15,30)$. HMAS-behandling er derfor ikke standard prosedyre for diffust storcellet B-cellelymfom i første remisjon $(3,25,27)$.

Den tidligere nevnte fase 2-studien for residiv av aggressive lymfomer inkluderte også ti pasienter med transformerte lymfomer i perioden 1989-93 (16). Fra 1999 til 2004 ble pasienter med transformerte lymfomer inkludert i en prospektiv fase 2studie ved fem norske universitetssykehus der HMAS-behandling ble gitt i første remisjon (17). Resultatene var gode sammenliknet med historiske kontrollpersoner, og sammenholdt med data fra flere retrospektive analyser bidro studien til at HMASbehandling er en mulighet ved transformerte lymfomer $(3,27)$.

Modne T-cellelymfomer er en heterogen gruppe sjeldne lymfomer med aggressivt klinisk bilde og dårlig prognose (31). HMASbehandling ble for denne gruppen i årene 1990-2000 gitt ved kjemosensitivt residiv (19). Fra 2001 til 2007 ble pasienter med flere typer av modne T-cellelymfomer inkludert i en prospektiv fase 2-studie i regi av Nordisk lymfomgruppe hvor de fikk HMASbehandling i første remisjon. Denne studien viste gode resultater - femårs totaloverlevelse og progresjonsfri overlevelse på henholdsvis $51 \%$ og $44 \%$ (18). Studien bekreftet resultatene fra en mindre tysk fase 2-studie (32). Dette regimet er nå ansett som et etablert behandlingsalternativ for systemiske varianter av modne aggressive T-cellelymfomer $(3,25,27)$. 
For mantelcellelymfom (stadium II-IV) har Nordisk lymfomgruppe gjennomført tre prospektive fase 2-studier med HMASbehandling i første remisjon (MCL-1,-2 og -3). Resultatene fra MCL-1 (pasienter inkludert 1996-2000) var skuffende og ikke vesentlig bedre enn for historiske kontrollpersoner behandlet med standard kjemoterapi alene. En forklaring på dette var at få pasienter oppnådde god remisjon av induksjonsbehandlingen med doseintensivert CHOP (maksi-CHOP) uten rituximab (21). I MCL-2-studien (inklusjon i perioden 2000-06) ble både høydose cytarabin og rituximab lagt til induksjonsbehandlingen. Dette førte til økt remisjonsrate - fra $76 \%$ i MCL-1 til 96\% i MCL-2 samt median totaloverlevelse på over ti år sammenliknet med tidligere tre år $(21,22)$. Basert på resultatene fra MCL-2-studien og en tysk randomisert studie (33) er HMAS-behandling i dag regnet som etablert prosedyre ved mantelcellelymfom i første remisjon $(3,25,27)$.

En randomisert europeisk multisenter fase 3-studie med norsk deltakelse der pasienter med residiv av follikulært lymfom var inkludert, ble gjennomført i perioden 1993-97. Det ble rekruttert færre pasienter enn ønsket, men det var høyere progresjonsfri overlevelse og totaloverlevelse etter HMASbehandling enn etter standard kjemoterapi (20). HMAS-behandling har siden vært en mulighet for pasienter med residiv av follikulært lymfom $(3,25,27,34)$.

Per i dag er altså HMAS-behandling etablert prosedyre eller en mulighet ved en rekke kliniske situasjoner hos lymfompasienter. Oppdaterte retningslinjer ligger på Helsedirektoratets nettsider (3).

\section{Diskusjon}

HMAS-behandling er dyrt og ressurskrevende. Bare transfusjon av autologe stamceller har i 2013 en DRG-vekt på 6,34, som betyr at et gjennomsnittlig slikt forløp er beregnet å koste ca. 250000 kroner. Et fullstendig pasientforløp som også inkluderer utredning, stamcellehøsting, oppfølging og komplikasjonsbehandling vil koste enda mer. Selv om HMAS-behandling er en intensiv prosedyre og kan medføre komplikasjoner, gir den en betydelig overlevelsesgevinst ved flere lymfomtyper.

Denne historiske oversikten viser et eksempel på kunnskapsbasert innføring av en behandlingsmetode ut fra systematisk forskningsaktivitet der norske miljøer har vært med i internasjonale kliniske studier. Dette har sikret en stadig utvikling og samtidig bidratt til å gi norske lymfompasienter et best mulig behandlingstilbud.

I Norge har HMAS-behandling nå vært et alternativ ved lymfomer i 25 år. Behand- lingen var de første årene ansett som utprøvende og ble gjennomført i små nasjonale fase 2-studier ved noen få indikasjoner og med strenge inklusjonskriterier. Etter hvert er behandlingen blitt prøvd ut for flere indikasjoner i internasjonale prospektive fase 2og fase 3-studier og er blitt etablert som standard prosedyre eller som et alternativ ved en rekke indikasjoner basert på disse resultatene. Norske retningslinjer for bruk av HMAS-behandling ved maligne lymfomer er således basert på funn i kliniske studier og samsvarer med europeisk og amerikansk praksis $(25,27)$.

Dokumentasjonskravene som er formulert i Statens helsetilsyns rapport fra 1995 er i stor grad blitt fulgt der dette har vært mulig. I enkelte tilfeller kan innføring av HMAS-behandling ha vært basert på mindre streng bruk av kriteriene, som for eksempel gevinst i progresjonsfri overlevelse, ikke totaloverlevelse. Ved flere randomiserte studier har pasienter i kontrollarmen fått HMAS-behandling i neste remisjon, slik at gevinsten i totaloverlevelse blir vanskeligere å dokumentere. Pasientgrunnlaget for noen lymfomtyper, for eksempel transformerte lymfomer, er også for lite til at man kan gjennomføre prospektive randomiserte studier. Behandlingsindikasjonen vil av og til være relativ, spesielt for follikulære og transformerte lymfomer, og en klinisk avveining av gevinst mot økt risiko for alvorlige bivirkninger må gjøres.

Den rolle høydosebehandling med auto$\log$ stamcellestøtte har i håndteringen av lymfomer har endret seg og vil fortsette å endre seg i takt med innføring av nye terapiformer. De siste tiårene er overlevelsen ved flere lymfomtyper markert forbedret. Dette skyldes i stor grad nye behandlingsformer, spesielt immunterapi med antiCD20-antistoffet rituximab ved B-cellelymfomer. For flere av lymfomtypene er kunnskapsgrunnlaget for HMAS-behandling basert på studier gjennomført før innføringen av rituximab. Rituximab er nå inkorporert i så å si alle førstelinjebehandlinger for B-cellelymfomer, og dette har ført til færre tilbakefall. Pasienter som likevel får et tidlig tilbakefall etter behandling med et regime som inneholder rituximab, responderer dårligere på annenlinjebehandling, inkludert HMAS-behandling, enn tidligere (35). Det er derfor behov for nye studier og utvikling av bedre behandlingsregimer, spesielt med tanke på å bedre induksjonsterapien før høydosebehandling med autolog stamcellestøtte.

Vi takker Øystein Fodstad, Arne Høiby, Steinar Funderud, Erlend Smeland, Eldbjørg Vorkinn og Eva Baggerød for deres bidrag til etablering og utvikling av HMAS-programmet.

\section{Knut Bjøro Smeland (f. 1982)}

er lege i spesialisering i onkologi og stipendiat ved Nasjonal kompetansetjeneste for seneffekter etter kreftbehandling, Oslo universitetssykehus.

Forfatter har fylt ut ICMJE-skjemaet og oppgir ingen interessekonflikter.

\section{Cecilie E. Kiserud (f. 1966)}

er ph.d., overlege i onkologi og postdoktor ved Nasjonal kompetansetjeneste for seneffekter etter kreftbehandling, Oslo universitetssykehus.

Forfatter har fylt ut ICMJE-skjemaet og oppgir ingen interessekonflikter.

\section{Grete F. Lauritzsen (f. 1959)}

er dr.med. og overlege ved Lymfomseksjonen. Forfatter har fylt ut ICMJE-skjemaet og oppgir følgende interessekonflikter: Hun har mottatt reisestøtte fra Roche og Mundi Pharma.

\section{Alexander Fosså (f. 1968)}

er dr.med. og overlege ved Lymfomseksjonen. Forfatter har fylt ut ICMJE-skjemaet og oppgir ingen interessekonflikter.

\section{Jens Hammerstrøm (f. 1947)}

er professor dr.med. og overlege. Han er fagansvarlig for HMAS-behandlingen ved St. Olavs hospital og tidligere styremedlem i Norsk Lymfomgruppe.

Forfatter har fylt ut ICMJE-skjemaet og oppgir ingen interessekonflikter.

\section{Vidar Jetne (f. 1945)}

er medisinsk fysiker og tidligere avdelingsleder ved Avdeling for medisinsk fysikk.

Forfatter har fylt ut ICMJE-skjemaet og oppgir ingen interessekonflikter.

\section{Arne Kolstad (f. 1958)}

er dr.med., overlege ved Lymfomseksjonen og leder for Forskningsgruppen for immunterapi ved Oslo universitetssykehus, Radiumhospitalet. Han er leder for Norsk Lymfomgruppe. Forfatter har fylt ut ICMJE-skjemaet og oppgir ingen interessekonflikter.

\section{Gunnar Kvalheim (f. 1946)}

er dr.med. og spesialist i onkologi. Han er leder for Seksjon for celleterapi.

Forfatter har fylt ut ICMJE-skjemaet og oppgir ingen interessekonflikter.

\section{Jon Håvard Loge (f. 1953)}

er professor dr.med. og spesialist i psykiatri. Han er Leder for nasjonal kompetansetjeneste for seneffekter etter kreftbehandling, Oslo universitetssykehus.

Forfatter har fylt ut ICMJE-skjemaet og oppgir ingen interessekonflikter. 


\section{Turid Løkeland (f. 1966)}

er overlege.

Forfatter har fylt ut ICMJE-skjemaet og oppgir ingen interessekonflikter.

\section{Jon Magnus Tangen (f. 1945)}

er overlege.

Forfatter har fylt ut ICMJE-skjemaet og oppgir ingen interessekonflikter.

\section{Harald Holte (f. 1951)}

er dr.med., overlege, fagansvarlig ved Lymfomseksjonen og leder for Forskningsgruppen for lymfom ved Avdeling for kreftbehandling. Han er nestleder (tidligere leder) i Nordisk lymfomgruppe.

Forfatter har fylt ut ICMJE-skjemaet og oppgir ingen interessekonflikter.

\section{Stein Kvaløy (f. 1947)}

er professor dr.med. og spesialist i onkologi. Han er forskningsleder for Kreft, kirurgi og transplantasjonsklinikken og var med på å starte HMAS-behandling ved Radiumhospitalet. Forfatter har fylt ut ICMJE-skjemaet og oppgir ingen interessekonflikter.

\section{Litteratur}

1. Schmitz N, Linch DC, Dreger P et al. Randomised trial of filgrastim-mobilised peripheral blood progenitor cell transplantation versus autologous bone-marrow transplantation in lymphoma patients. Lancet 1996; 347: 353-7.

2. Swerdlow SH, Campo E, Harris NL et al. WHO Classification of tumours of haematopoietic and lymphoid tissues. 4. utg. Lyon: IARC, 2008

3. Nasjonalt handlingsprogram med retningslinjer for diagnostikk, behandling og oppfølging av maligne lymfomer nr. 987-82-8081-113-4/2012 Oslo: Norsk lymfomgruppe, 2012

4. Cancer in Norway 2010 - cancer incidence, mortality, survival and prevalence in Norway 2012. Oslo: Kreftregisteret, 2012

5. Freedman A. Follicular lymphoma: 2012 update on diagnosis and management. Am J Hematol 2012; 87: 988-95.

6. Bernstein SH, Burack WR. The incidence, natural history, biology, and treatment of transformed lymphomas. Hematology (Am Soc Hematol Educ Program) 2009; 2009: 532-41.

7. Osgood EE, Riddle MC, Matthews TJ. Aplastic anemia treated with daily transfusions and intravenous marrow. Case report. Ann Intern Med 1939; 13: 357-67

8. Lorenz E, Uphoff D, Reid TR et al. Modification of irradiation injury in mice and guinea pigs by bone marrow injections. J Natl Cancer Inst 1951; 12: 197-201.

9. Pegg DE, Humble JG, Newton KA. The clinical application of bone marrow grafting. Br J Cancer 1962: 16: 417-35.
10. Appelbaum FR, Herzig GP, Ziegler JL et al. Successful engraftment of cryopreserved autologous bone marrow in patients with malignant lymphoma. Blood 1978; 52: 85-95.

11. Bone-marrow autotransplantation in man. Report of an international cooperative study. Lancet 1986 2: $960-2$.

12. Schmitz N, Pfistner B, Sextro M et al. Aggressive conventional chemotherapy compared with highdose chemotherapy with autologous haemopoietic stem-cell transplantation for relapsed chemosensitive Hodgkin's disease: a randomised trial. Lancet 2002; 359: 2065-71.

13. Smeland S, Blystad AK, Kvaløy SO et al. Treatment of Burkitt's/Burkitt-like lymphoma in adolescents and adults: a 20-year experience from the Norwegian Radium Hospital with the use of three successive regimens. Ann Oncol 2004; 15: 1072-8.

14. Sweetenham JW, Santini G, Qian W et al. Highdose therapy and autologous stem-cell transplantation versus conventional-dose consolidation/ maintenance therapy as postremission therapy for adult patients with lymphoblastic lymphoma: results of a randomized trial of the European Group for Blood and Marrow Transplantation and the United Kingdom Lymphoma Group. J Clin Oncol 2001; 19: 2927-36.

15. Linch DC, Yung L, Smith P et al. Final analysis of the UKLG LYO2 trial comparing 6-8 cycles of $\mathrm{CHOP}$ with 3 cycles of $\mathrm{CHOP}$ followed by a BEAM autograft in patients $<65$ years with poor prognosis histologically aggressive NHL. Br J Haematol 2010; 149: 237-43.

16. Blystad A, Kvalheim G, Torlakovic E et al. Highdose therapy supported with immunomagnetic purged autologous bone marrow in high-grade B cell non-Hodgkin's lymphoma. Bone Marrow Transplant 1999; 24: 865-72

17. Eide MB, Lauritzsen GF. Kvalheim G et al. High dose chemotherapy with autologous stem cell support for patients with histologically transformed B-cell non-Hodgkin lymphomas. A Norwegian multi centre phase II study. Br J Haematol 2011; 152: 600-10.

18. d'Amore F, Relander T, Lauritzsen GF et al. Upfront autologous stem-cell transplantation in peripheral T-cell lymphoma: NLG-T-01. J Clin Oncol 2012; 30: 3093-9.

19. Blystad AK, Enblad G, Kvaløy SO et al. High-dose therapy with autologous stem cell transplantation in patients with peripheral T cell lymphomas. Bone Marrow Transplant 2001; 27: 711-6.

20. Schouten HC, Qian W. Kvaloy S et al. High-dose therapy improves progression-free survival and survival in relapsed follicular non-Hodgkin's lymphoma: results from the randomized European CUP trial. J Clin Oncol 2003; 21: 3918-27.

21. Andersen NS, Pedersen L, Elonen E et al. Primary treatment with autologous stem cell transplantation in mantle cell lymphoma: outcome related to remission pretransplant. Eur J Haematol 2003; 71: 73-80.

22. Geisler CH, Kolstad A, Laurell A et al. Long-term progression-free survival of mantle cell lymphoma after intensive front-line immunochemotherapy with in vivo-purged stem cell rescue: a nonrandomized phase 2 multicenter study by the Nordic Lymphoma Group. Blood 2008; 112: 2687-93.

23. Høydosebehandling med autolog stamcellestøtte ved maligne lidelser. Helsedirektoratets utredningsserie 1-951995. Oslo: Statens helsetilsyn, 1995.
24. Linch DC, Winfield D, Goldstone AH et al. Dose intensification with autologous bone-marrow transplantation in relapsed and resistant Hodgkin's disease: results of a BNLI randomised trial. Lancet 1993; 341: 1051-4.

25. Ljungman $\mathrm{P}$, Bregni $M$, Brune $M$ et al. Allogeneic and autologous transplantation for haematological diseases, solid tumours and immune disorders: current practice in Europe 2009. Bone Marrow Transplant 2010; 45: 219-34

26. Hoppe RT, Advani RH, Ai WZ et al. Hodgkin lymphoma Version 2.2013. National Comprehensive Cancer Network Clinical Practice Guidelines. www.jnccn.org/content/10/5/589.short (25.4.2013)

27. Zelenetz AD, Abramson JS, Advani RH et al. NonHodgkin's lymphomas Version 1.2013. National Comprehensive Cancer Network Clinical Practice Guidelines. www.jnccn.org/content/11/3/ 257.abstract (25.4.2013)

28. Bosly A, Coiffier B, Gisselbrecht C et al. Bone marrow transplantation prolongs survival after relapse in aggressive-lymphoma patients treated with the LNH-84 regimen. J Clin Oncol 1992; 10: 1615-23.

29. Philip T, Guglielmi C, Hagenbeek A et al. Autologous bone marrow transplantation as compared with salvage chemotherapy in relapses of chemotherapy-sensitive non-Hodgkin's lymphoma. N Engl J Med 1995; 333: 1540-5

30. Greb A, Bohlius J, Trelle S et al. High-dose chemotherapy with autologous stem cell support in firstline treatment of aggressive non-Hodgkin lymphoma - results of a comprehensive meta-analysis Cancer Treat Rev 2007; 33: 338-46.

31. Schmitz N, Trümper L, Ziepert M et al. Treatment and prognosis of mature T-cell and NK-cell lymphoma: an analysis of patients with T-cell lymphoma treated in studies of the German HighGrade Non-Hodgkin Lymphoma Study Group. Blood 2010: 116: 3418-25.

32. Reimer P, Rüdiger T, Geissinger E et al. Autologous stem-cell transplantation as first-line therapy in peripheral T-cell lymphomas: results of a prospective multicenter study. J Clin Oncol 2009; 27: $106-13$

33. Dreyling M, Lenz G, Hoster E et al. Early consolidation by myeloablative radiochemotherapy followed by autologous stem cell transplantation in first remission significantly prolongs progressionfree survival in mantle-cell lymphoma: results of a prospective randomized trial of the European MCL Network. Blood 2005; 105: 2677-84.

34. Schaaf M, Reiser M, Borchmann P et al. High-dose therapy with autologous stem cell transplantation versus chemotherapy or immuno-chemotherapy for follicular lymphoma in adults. Cochrane Database Syst Rev 2012; 1: CD007678.

35. Gisselbrecht C, Glass B, Mounier N et al. Salvage regimens with autologous transplantation for relapsed large B-cell lymphoma in the rituximab era. J Clin Oncol 2010; 28: 4184-90.

Mottatt 6.3. 2013, første revisjon innsendt 2.5. 2013, godkjent 25.6. 2013. Medisinsk redaktør Sigurd Høye. 